\title{
Peripheral T-cell lymphoma of the eyelid
}

This article was published in the following Dove Press journal:

Clinical Ophthalmology

22 September 2009

Number of times this article has been viewed

\section{Makoto Ishikawa \\ Hiroshi Watabe \\ Masahiro Hayakawa \\ Takeshi Yoshitomi \\ Department of Ophthalmology, Akita University Faculty of Medicine, Akita, Japan}

Correspondence: Makoto Ishikawa Department of Ophthalmology, Akita University Faculty of Medicine, I-I-I Hondo, Akita 0 I0-8543, Japan

$\mathrm{Tel}+8 \mathrm{I}$ I8 834 II II

Fax +8|| $8836262 \mid$

Email mako@med.akita-u.ac.jp
Purpose: To report a case of a 25-year-old woman with previously treated peripheral T-cell lymphoma (PTCL) presenting with a recurrent lower eyelid lesion.

Patients and method: Case report.

Results: A 25-year-old young woman with previously treated PTCL noted an induration in the skin of her left lower eyelid. Upon diagnosis of a chalazion, antibiotic eye drops and ointments as well as steroid eye drops were administered. However, the condition worsened rapidly and swelling of the lower eyelid became remarkable. An excisional biopsy revealed that the palpebral lesion was diagnosed as recurrence of PTCL. Electron irradiation was applied as a radical treatment, and the prognosis was satisfactory without recurrence at 10 months after the last irradiation.

Conclusions: Although lymphoma isolated to the ocular adnexa is rare, it should always be included in the differential diagnosis of any patient presenting with progressive swelling of the eyelid or ocular region.

Keywords: peripheral T-cell lymphoma, chalazion, eyelid

\section{Introduction}

Peripheral T-cell lymphoma (PTCL) represents a broad spectrum of disease with several different manifestations. PTCL often occurs in the extremities, but rarely in the eyelid. Periocular involvement by PTCL usually occurs in the setting of the Sézary syndrome or mycosis fungoides, which is a variant of PTCL. ${ }^{1-4}$ We report a case of a 25-year-old young woman with previously treated PTCL presenting with a recurrent lower eyelid lesion.

\section{Case report}

The patient's history dates back to 2006 when she had multiple skin lesions that were diagnosed as PTCL and subsequently excised. Submandibular and parotid lymph nodes were palpable, but there was no swelling of the liver or spleen. Blood tests were negative for adult T-cell leukemia antibody and human immunodeficiency virus (HIV) antibody and soluble interleukin-2 receptor was within normal range. No other lesion was detected by gallium scintigraphy or systemic computed tomography. A bone marrow trephine biopsy did not show the involvement of lymphoma. Immunostaining revealed the cells to be positive for CD3 and CD5, but negative for CD30, CD10, and CD75. Based on the findings, the patient was classified as PTCL Stage IVB according to the new World Health Organization classification. ${ }^{5}$ As the patient was chemorefractory 
against initial treatment with combined cyclophosphamide, deoxorubicin, vincristine, and prednisone, she underwent allogenic stem cell transplantation from a matched nonsibling donor in March 2007 after salvage treatment with cyclophosphamide, cytosine arabinoside, etoposide, and dexamethasone. Transplant-conditioning therapy was cyclophosphamide, $2900 \mathrm{mg}$ /day for three days, plus total body irradiation for three days (total 12 Gy). Graft-versus-host disease prophylaxis was provided with cyclosporine A and prednisolone. Cyclosporin levels were maintained between 300 and $400 \mu \mathrm{g} / \mathrm{L}$ until tapering was initiated. Initial dose of prednisolone was $17.5 \mathrm{mg}$ per oral.

In January 2008, the patient presented to our department to check for any ocular manifestations of the graft-versus-host disease. At that time, significant superficial punctate keratopathy was noted in both eyes. Systemic skin and eyelids were macroscopically normal. Systemic lymph nodes were not palpable, and there was no swelling of the liver or spleen. The superficial punctate keratopathy significantly improved with eyedrops containing hyaluronan.

On July 11, 2008, the patient noted an induration in the skin of her left lower eyelid (Figures 1A, B). Conjunctival congestion and pain were present. Upon diagnosis of an acute chalazion, conservative management was used. However, the condition worsened rapidly, and swelling of the lower eyelid became remarkable (Figures 1C, D).
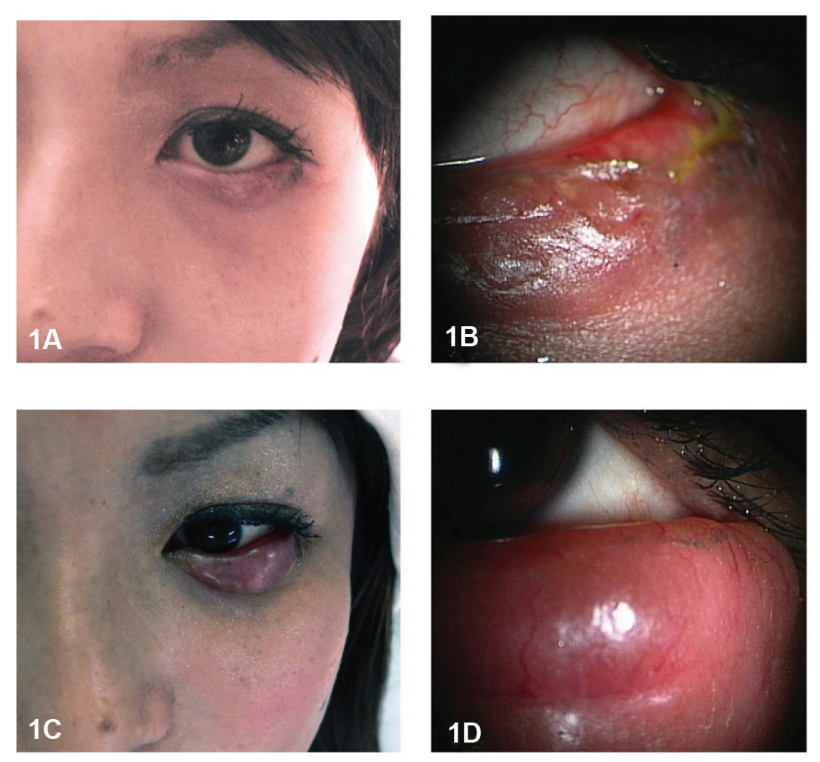

Figure I A) Patient with chalazion-like induration of the left lower eyelid on July II, 2008. B) High magnification of the lower eyelid with chalazion-like presentation. C) After one month, induration of the lower eyelid became rapidly enlarged. Note a diffuse, erythematous, thickened lower eyelid. D) High magnification of the thickened lower eyelid.
On August 25, 2009, the patient underwent an excisional biopsy of the palpebral lesion after informed consent. A retention cyst in chalazion was not detected during the intraoperative microscopic examination. Pathological examination demonstrated that medium-sized lymphoma cells with round nuclei (Figures 2A, B) had infiltrated subcutaneously. Immunostaining revealed the cells to be positive for $\mathrm{CD} 3$ (Figures $2 \mathrm{C}$ ). Considering these results, the palpebral lesion was diagnosed as recurrence of PTCL.

As the lesion was limited to the left lower eyelid, 25.2 Gy electron irradiation was applied as a radical treatment. Globe shielding was used to help prevent radiation retinopathy. The eyelid tumor was dramatically improved after irradiation (Figures 2D, 2E). The prognosis was satisfactory without recurrence at 10 months after the last irradiation.

\section{Discussion}

Ocular manifestations of PTCL can include both intraocular and extraocular conditions. ${ }^{1-4}$ Cook and colleagues ${ }^{6}$ reported that eyelid ectropion was the most common findings in their patients with PTCL, though other ocular manifestations, including eyelid thickening or edema, placoid tumor, tight skin, blepharitis, and corneal abnormalities, were also found. Stenson and Ramsay ${ }^{7}$ found eyelid tumors in eight of 30 consecutive patients with mycosis fungoides diagnosed by biopsy. Isolated PTCL of the eyelid is rare. ${ }^{8,9}$ Gilbertson and colleagues ${ }^{1}$ reported a case of a 38-year-old acquired immunodeficiency syndrome (AIDS) patient with isolated eyelid PTCL, and found only eight previous reports of isolated PTCL, most diagnosed as mycosis fungoides. In this type of lymphoma, relapses are common and can produce an indolent course. Kirsch and colleagues reported a patient with multiple recurrences of systemic T-cell lymphoma after initial presentation with only an eyelid mass that was treated with systemic chemotherapy and local radiation. ${ }^{4}$

The present case was a single episode of lymphoma of the eyelid with clinical symptoms resembling a chalazion. However, an excisional biopsy of the current lesion confirmed the recurrence of the actual tumor and so ruled out a chalazion. The current case still requires close follow-up observation, particularly of the skin around the lesion. When radiation therapy is used for eyelid lesions, great care must be taken with ocular side effects, including xerophthalmia and radiation retinopathy. ${ }^{6}$ Although lymphoma isolated to the ocular adnexa is rare, it should always be included in the differential diagnosis of any patient presenting with progressive swelling of the eyelid or ocular region, particularly with a history of lymphoma. 

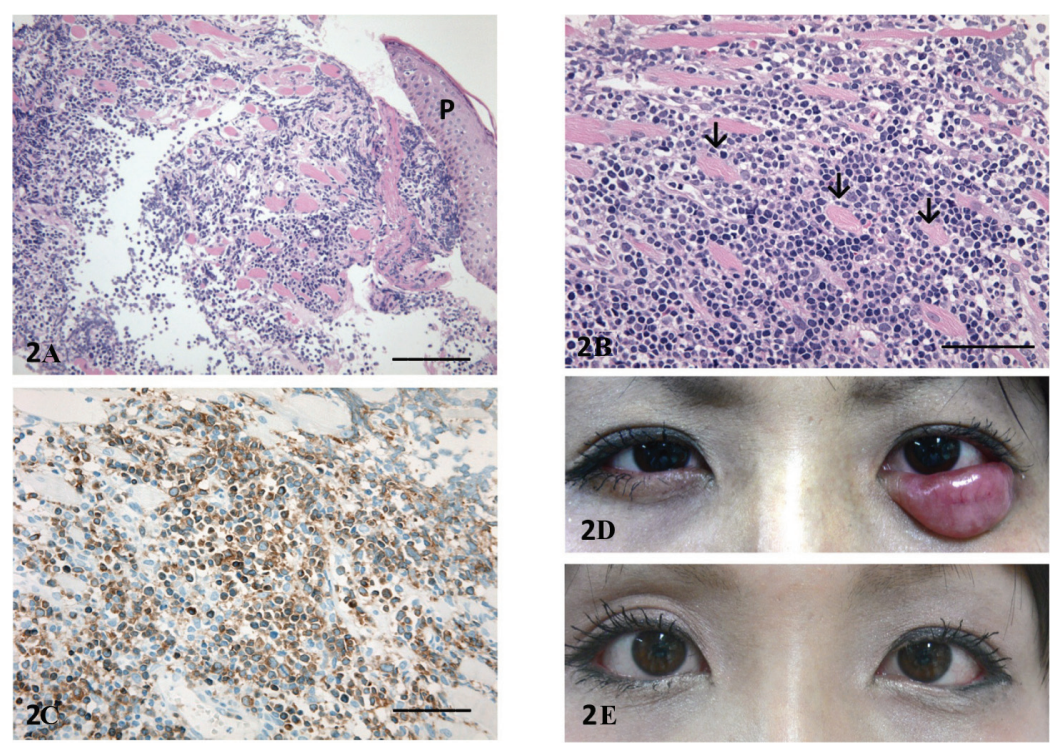

Figure 2 A) Light micrograph of hematoxylin and eosin stained eyelid biopsy specimen. Lymphoma cells were infiltrated into the subcutaneous tissue. P, palpebral skin; Bar $=200 \mu \mathrm{m}$. B) High magnification of the lymphoma cells infiltrated in the orbicular muscles (arrows). Bar $=100 \mu \mathrm{m}$. C) Light micrograph of eyelid biopsy specimen immunostained with CD3 antibody. CD3 positive lymphoma cells were distributed in the subcutaneous tissue. Bar $=100 \mu \mathrm{m}$. Photographs of eyelids before $\mathbf{D}$ ) and after irradiation E) The eyelid tumor was dramatically improved after irradiation.

\section{Disclosures}

The authors report no conflicts of interest in this work.

\section{References}

1. Gibertson EO, Hunt SJ, Spellman MC. Cutaneous T-cell lymphoma of the eyelid in a patient with acquired immunodeficiency syndrome. Cutis. 1996;56:437-440

2. Meekins B, Proia AD, Klintworth GK. Cutaneous T-cell lymphoma presenting as a rapidly enlarging ocular adnexal tumor. Ophthalmology. 1985;92:1288-1293.

3. Henderson JW, Banks PM, Yeatts RP. T-cell lymphoma of the orbit. Mayo Clin Proc. 1989;64:940-944.

4. Kirsch LS, Brownstein S, Codere F. Immunoblastic T-cell lymphoma presenting as an eyelid tumor. Ophthalmology. 1990;97:1352-1357.
5. Jaffe ES, Harris NL, Stein H, Vardiman JM, editors. Pathology and Genetics of Tumors of Haematopoietic and Lymphoid Tissues. Lyon, France: IARC Press; 2001.

6. Cook BE Jr, Bartley GB, Pittelkow MR. Ophthalmic abnormalities in patients with cutaneous T-cell lymphoma. Ophthalmology. 1999;106:1339-1344.

7. Stenson S, Ramsay DL. Ocular findings in mycosis fungoides. Arch Ophthalmol. 1981;99:272-277.

8. Mito H, Kakizaki H, Tsuji H, et al. Peripheral T-cell lymphoma of the eyelid. Jpn J Ophthalmol. 2006;50:388-390.

9. Ing E, Hsieh E, Macdonald D. Cutaneous T-cell lymphoma with bilateral full-thickness eyelid ulceration. Can J Ophthalmol. 2005;40: $467-468$.
Clinical Ophthalmology

\section{Publish your work in this journal}

Clinical Ophthalmology is an international, peer-reviewed journal covering all subspecialties within ophthalmology. Key topics include: Optometry; Visual science; Pharmacology and drug therapy in eye diseases; Basic Sciences; Primary and Secondary eye care; Patien Safety and Quality of Care Improvements. This journal is indexed on

\section{Dovepress}

PubMed Central and CAS, and is the official journal of The Society of Clinical Ophthalmology (SCO). The manuscript management system is completely online and includes a very quick and fair peer-review system, which is all easy to use. Visit http://www.dovepress.com/ testimonials.php to read real quotes from published authors. 